\title{
Justification of parameters mining and technological structure of modular mine sites in terms water disposal
}

\author{
Roman Shishkov ${ }^{1, *}$, and Valery Fedorin ${ }^{1}$ \\ ${ }^{1}$ Federal research center coal and coal chemistry SB RAS, Kemerovo region, Kemerovo, Sovetsky \\ Prospekt, 18, 650991, Russia
}

\begin{abstract}
The high cost of any traditional coal mines consists of many factors their operation, one which is basically drainage. In mines and sections Russia, on average, for each ton coal mined, more than $2 \mathrm{~m}^{3}$ water is pumped from mine workings to day surface. For this work, more than 10 thousand pumping units with a total installed capacity about 1 million $\mathrm{kW}$ are used at mining enterprises. Therefore, rational design and proper operation, in particular, drainage plants mining enterprises are important technical and economic tasks today and in future, which leads to increased production volumes and a transition to a new stage in development coal industry using new technologies. The application mining technology structure mine sites located on a coal mine is considered. The result is that at design stage it becomes possible to highlight use of water pumping measures only at stage preparatory mine workings, reducing production costs for equipment and its operation, volumetric work, mine workings for water collectors and allocation personnel from drainage site to more significant work . A comparative analysis of two options is given, in terms efficiency wastewater disposal, namely actual situation of a certain period at enterprise SUEK-Kuzbass JSC mine Taldinskaya Zapadnaya-2 and the use mine sites.
\end{abstract}

\section{Introduction}

The widespread use an open method coal mining in absence land reclamation over past 20 years causes social tension in society, but its great advantages make it attractive to investors $[1,2]$.

It should be noted that many quarries coal basins come close to boundary of profitable mining and the maximum stripping ratio [3].

A promising direction for development mining regions is extraction of coal reserves not previously mined by traditional technologies. The development these reserves is not carried out by underground and open-cast mining methods in most cases on basis "economic feasibility" factor. For these reasons, tens of millions tons valuable coal are attributed to offbalance reserves and losses. The development remaining reserves opened by open pits, the

\footnotetext{
*Corresponding author: $\underline{\text { rshis@ya.ru }}$
} 
volume of which continues to increase, makes it possible to increase completeness extraction reserves from subsoil by mine sites, thereby extending service life existing mining enterprises and taking a number measures to positive side $[4,5]$.

This article discusses use mining structure "coal cut - mine sites" [6]. One of such factors to reduce cost coal mining is the rational use of water drainage.

\section{Results}

The structure is represented in form excavation columns mine sites located at fall a shallow seam, opening seam from side coal mine 1 through a longitudinal-transverse or longitudinaldeep development system. The mining extraction column is carried out according to uprising formation 5, thereby forming a flooded mined space 6 behind face. Due to separate preparation excavation sites, water pumping after launch lava is not required. Thus, water is pumped into a specially allocated sump 2 for each modular mine section from preparatory faces 3 during mining and at lowest point mounting chamber of prepared extraction column until lava starts. This technological structure is presented at (Fig. 1).

The technology can be applied to most fields with a shallow bed. As an example, consider the Taldinsky Zapadny-2 site located on the Taldinskoye field in the central part Erunakovsky geological and economic region Kuzbass.

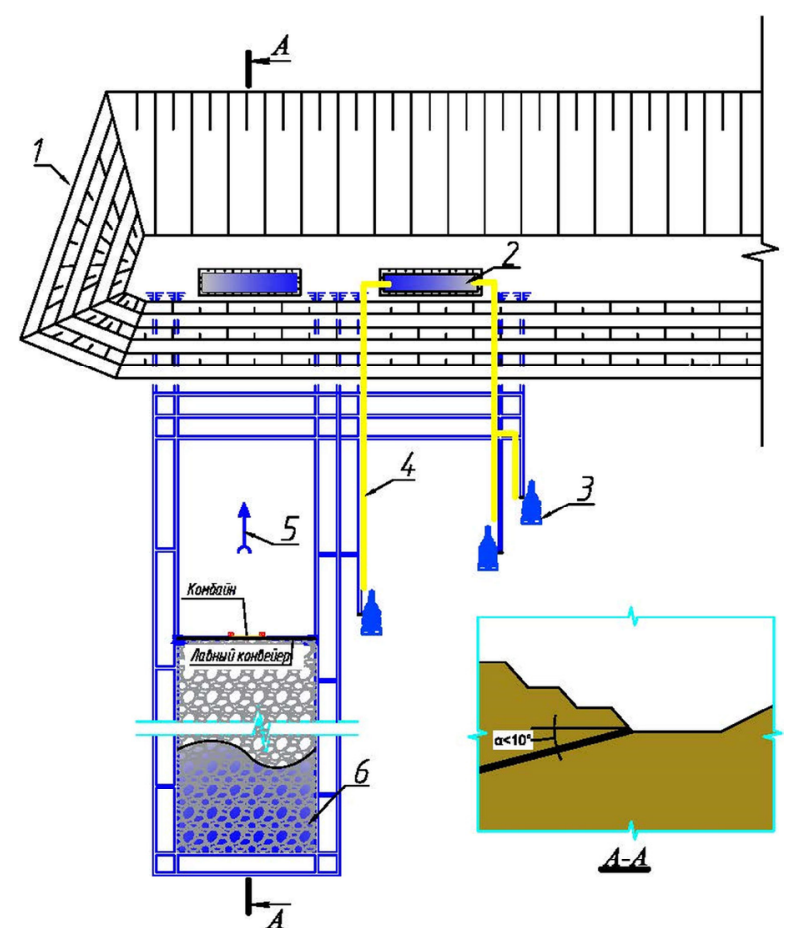

Fig. 1. The technological scheme work water disposal in treatment and preparatory faces; where 1 is a longitudinal-transverse coal section; 2 - sump; 3 - roadheader; 4 - pipeline for drainage from preparatory faces; 5 - direction of mining a mining column; 6 - flooded worked out space.

Figure 2 shows a graph growth water inflows into underground mine workings Taldinskaya Zapadnaya-2 mine from beginning its operation in period from 1999 to 2011 . 
We have before us a typical growth schedule for water inflows into a mine due to an increase in mining area since its construction. According to data of indicated period, it is possible to determine effect use mining technology structure, taking into account initial equipment sump plants. According to schedule, average water inflow reaches $240 \mathrm{~m}^{3} / \mathrm{h}$ in 2011 .

Due to constant deepening mine workings, there is a constant displacement internal watersheds, which it is simply impossible to determine position in space at the moment, this is a multivariate analysis that requires long-term monitoring observations. And it is a fact that formed main drainage system and local water collectors take on entire load block mining mine throughout its operation. [7]

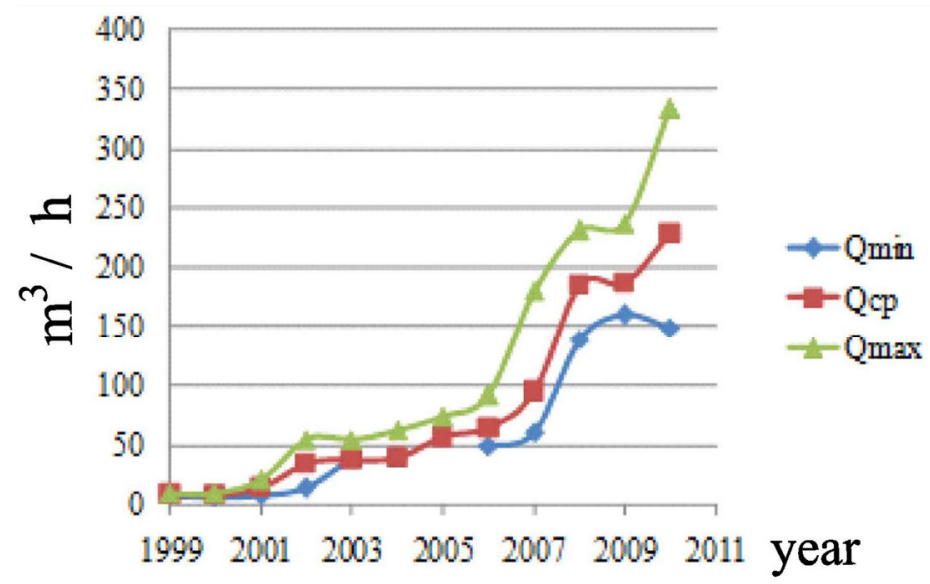

Fig. 2. Water inflow Taldinskaya Zapadnaya-2 mine.

\section{Discussion}

Abroad, a wide selection calculation water inflows close to used technological methods is used, taking into account local geological and metamorphic composition [8, 9]. Our calculation was carried out according to generally accepted Russian standards. In this regard, to determine average water inflow over entire service life enterprise, we consider various depth distribution circuits. Water inflow calculations are performed for two intervals thickness to be triggered, and then summed up. The calculation was performed at time completion development site using the "big well" method.

Thickness is from +85 to the horizon \pm 0 (depth of mining of the road. Taldinskaya Zapadnaya-2). In the design scheme, a semi-limited formation with one impenetrable contour, according to formula (1.), the water inflow is $32 \mathrm{~m}^{3}$ / hour.

$$
Q_{1}=\frac{2,73 \cdot k \cdot m \cdot S}{\lg \frac{2 \cdot L_{1}}{r_{0}}},
$$

where $r_{0}$ - reduced radius, $\mathrm{m} ; L_{1}$ - distance from the intake line to constant pressure circuit, $\mathrm{m} ; k$ - filtration coefficient, $\mathrm{m} /$ day; $m$ - aquifer thickness, $\mathrm{m} ; S$ - lowering the water level, $\mathrm{m}$.

Thick from the horizon \pm 0 до -200 $\mathrm{m}$. In the design scheme, an unlimited reservoir, according to formula (2.), the water inflow is $341 \mathrm{~m}^{3} /$ hour: 


$$
Q_{2}=\frac{5,46 \cdot k \cdot m \cdot S_{1}}{\lg \frac{2,25 \cdot a \cdot t}{r_{0}^{2}}},
$$

where $a$ - piezoconductivity coefficient, $\mathrm{m}^{2} /$ day; $t$ - business hours, days.

The verification calculation total inflow at end depreciation period to work site is carried out by balance method.

Water inflow due to natural resources is $96 \mathrm{~m}^{3}$ / hour according to formula:

$$
Q_{p e c}=\frac{O_{c} \cdot F \cdot \eta}{365},
$$

where $O_{\mathrm{c}}$ - amount of precipitation, in meters (long-term average $0.519 \mathrm{~m}$ ); $\eta$ - coefficient of infiltration in fractions a unit for Kuzbass is 0.15 .

Water inflow due to natural (static) reserves is $307 \mathrm{~m}^{3} /$ hour, which is determined by formula:

$$
Q_{3 a n}=\frac{m \cdot \mu \cdot F}{t},
$$

where $\mu$ - rock loss, for a fractured zone equal 0,035 .

The total inflow is summarized and will be:

$$
Q=Q_{\text {pec }}+Q_{\text {zan }}=96+372=403 \mathrm{~m}^{3} / \text { hour }
$$

The discrepancy between calculated values total water inflows made by two methods is less than $10 \%$. For further calculations, we take an integer value of $400 \mathrm{~m}^{3} /$ hour.

In our case, it is advisable to separate water inflows for preparatory and treatment works mining and technological structure mine sites, since each mine site operates separately. Obviously, in treatment works after the launch lava, drainage plants are not required, so result total inflow is divided in two, which ultimately amounts to $200 \mathrm{~m}^{3}$ / hour.

Based on calculation resulting water inflow for Taldinskaya Zapadnaya-2 and mine sites, we determine energy consumption with original equipment of mine drainage installations and their quantity depending on total water inflow.

The calculation shows that average annual electricity consumption of a sump plant $W_{\mathrm{r}}$ is respectively for Taldinskaya Zapadnaya-2, 530,710 kWh, mine sections $274,740 \mathrm{kWh}$ and is determined by formula:

$$
W_{r}=\frac{25,2 \cdot Q_{p} \cdot H_{p} \cdot\left[\left(365-T_{\max }\right) \cdot t_{h} \cdot n_{\mathrm{work}}+T_{\max } \cdot t_{\max } \cdot n_{\max }\right]}{3600 \cdot \eta \cdot \eta_{\mathrm{we}} \cdot \eta_{c}}
$$

where $Q_{\mathrm{p}}$ and $H_{\mathrm{p}}$ - productivity and pressure in operating mode for one pump unit during pumping through an individual pipeline, $\mathrm{m}^{3} / \mathrm{h}$ and $\mathrm{m} ; T_{\max }$ - duration of flood periods for 1 year, days; $t_{\mathrm{h}}$ и $t_{\max }$ - duration of pumping out normal and maximum daily inflow of water into mine workings, $\mathrm{h} ; n_{\text {work }}$ и $n_{\max }-$ number of working pumps during pumping out normal and maximum water inflow into mine workings, units; $\eta$ - pump efficiency; $\eta_{\mathrm{we}}$ - motor efficiency; $\eta_{\mathrm{c}}$ - efficiency of the power line from transformer to pump motor.

Thus, specific energy consumption per $1 \mathrm{~m}^{3}$ of water $W_{\text {уд }}$ for each option is determined by formula, calculation results are displayed on graph (Fig. 3), $\mathrm{kWh} / \mathrm{m}^{3}$ :

$$
W_{\mathrm{sp}}=\frac{W_{r}}{\left.\left[Q_{n} \cdot\left(365-T_{\max }\right) \cdot t_{n_{\text {work }}} \cdot Q_{\max } \cdot T_{\max } \cdot t_{\max } \cdot n_{\max }\right)\right]}
$$

where $Q_{\mathrm{n}}$ and $Q_{\max }$ - duration installation when pumping normal and maximum flow, $\mathrm{m}^{3} / \mathrm{h}$. 


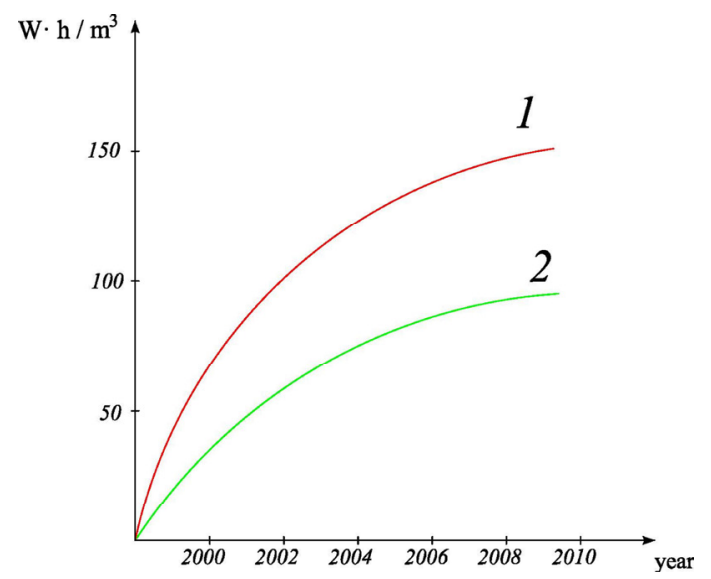

Fig. 3 - Specific energy consumption per $1 \mathrm{~m}^{3}$ of water, $\mathrm{W} \mathrm{h} / \mathrm{m}^{3}$; where 1 - Taldinskaya Zapadnaya -2; 2 - Mine sites

According to calculated water inflows, specific energy consumption per $1 \mathrm{~m}^{3}$ of water is reduced by 2 times for mine sites. Specific energy consumption drainage plants per ton production $\mathrm{E}_{\mathrm{sp}}$ similarly reduced by 2 times under condition equal production (Figure 4 ) and is determined by formula, $\mathrm{W} \mathrm{h} / \mathrm{t}$ :

$$
E_{\mathrm{sp}}=W_{r} / A_{\text {ann }}
$$

where $A_{\text {ann }}$ - annual mining output, $\mathrm{t} /$ year.

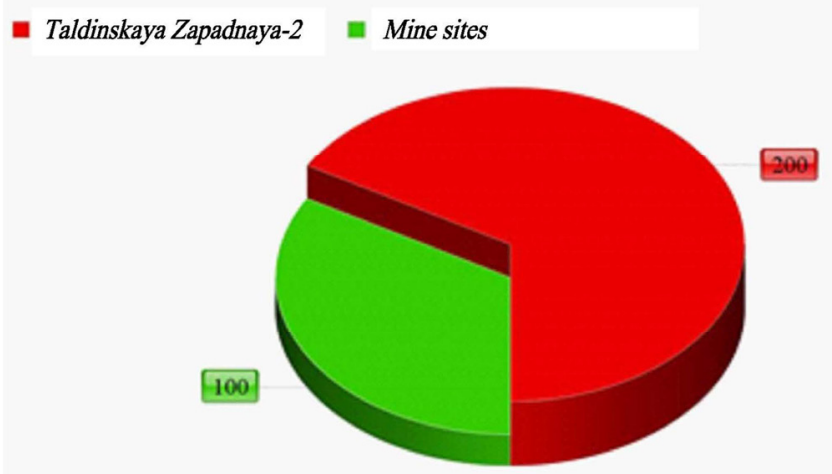

Fig. 4. Specific energy consumption drainage plants per ton production, $\mathrm{W} \mathrm{h} / \mathrm{t}$.

\section{Conclusion}

Thus, when using mining and technological structure mine sites, effect water disposal and a partial reduction in cost coal production are significantly increased by solving technical and economic problem regarding drainage installations mining enterprises.

In scientific literature there are currently not enough scientific calculations main sump plant mine, which allow us to determine cost. As a result analysis, above costs may reflect cost of electricity for pumping water from mine, depreciation for equipment, staff salaries, 
mining tunnels for catchments and drainage, which is caused by economic availability when using technology on a quarry.

In addition to economic effect, it can be noted that:

- system does not require complex infrastructure, complex ventilation systems, like traditional underground mining, this advantage provides a lower cost of production, as well as a quick and easy way to work out mining columns;

- the method is flexible, as the infrastructure can be easily moved, using less labor, as a result, it can be used for contract work.

\section{References}

1. J. Oya, H. Shimanda, T. Sasaoka, M. Ichinose, Fundamental Study on AMD-prevention by Compacted Waste Rocks at Berau Coal Mine, Indonesia (Novel Carbon Resource Science, Houston, 2009)

2. H. Shimanda, T. Sasaoka, Effective Assessment Methods of Soil Erosion Control in Indonesian Open Pit Mine (PCEMP, Berlin, 2014)

3. K. Matsui, T. Sasaoka, M. Ichinose, Some Consideration in Underground Mining Systems for Extra-thick Coal Seam (PISMRMD, Berlin, 2010)

4. A. Hamanaka, T. Sasaoka, H. Shimada, Application of Punch Mining System to Indonesian Coal Mining Industry (PISMND, Sydney, 2011)

5. S. Shibata, N. Z. Lin, H. Shimada, A. Hamanaka, Preliminary Study on Design of Longwall Mining from Final Highwall at Mae Moh Lignite Mine in Thailand (PMPES, Bangkok, 2013)

6. V. A. Fedorin, V. Ya. Shakhmatov, B. A. Anferov, L. V. Kuznetsova, IOP Conf. Series: Earth and Environmental Science, 262, 012015 (2019)

7. G. A. Bruggeman, Dev. Wat. Sci., 46, 331 (1999)

8. ILRI Description of principles, user manual and case studies (ILRI Wageningen, Amsterdam, 2017)

9. G. Van Drecht, Calculation of steady groundwater flow to ditches (National Institute for Water Supply, Amsterdam, 1983) 